\title{
PELATIHAN PEMBELAJARAN BERBASIS E-LEARNING
}

\author{
Muhamad Iksan', ${ }^{1}$ gusalim $^{2}$, La Aba $^{3}$, Kusrini $^{4}$ \\ Fakultas Keguruan dan Ilmu Pendidikan Universitas Muhammadiyah Buton Jl. \\ Betoambari No. 36 Kota Baubau, 93721, Indonesia. \\ Email: m.iksan@umbuton.ac.id
}

\begin{abstract}
Abstrak
Pelatihan dalam bentuk pengabdian ini bertujuan untuk memberikan panduan terperinci tentang merancang dan mengembangkan sebuah kursus e-learning untuk pelatih dan perancang instruksional yang baru mengenal desain e-learning. Juga memberikan konsep dasar dan informasi tentang proses dan sumber daya yang terlibat dalam e-learning pengembangan, yang mungkin menarik bagi peserta didik serta mempermudah peserta didik dalam pembelajaran. Metode yang digunakan web-based learning dengan pendampingan langsung secara visual dengan mempraktikan. E-learning dapat dilihat sebagai pembelajaran berbantuan komputer, dan sebagai pedagogi untuk pembelajaran yang berpusat pada peserta didik dan kolaboratif. Perkembangan awal dalam e-learning difokuskan pada komputer belajar dengan bantuan, di mana sebagian atau seluruh konten pembelajaran disampaikan secara digital. Upaya pemerintah dalam meningkatkan sumberdaya manusia harus dibarengi dengan kemampuan teknologi, saat ini segala sesuatu diperhadapkan dengan teknologi dalam menuju revolousi indistri 4.0 seiring dengan berkembangnya teknologi, maka pembelajaran pula semakin meningkat dalam pelakasanaanya. Oleh karena itu ini dianggap sangat penting, seperti halnya yang dilakukan oleh Universitas Muhammadiyah Buton dalam mengintegrasikan teknologi informasi ke dalam pendidikan. Ini mengadaptasi proses belajar peserta didik dengan memperkenalkan sistem pembelajaran online dengan penggunaan website. Atmosfir akademik dalam pemanfaatan blog, google, wikipedia, Academia portal, repositori, perpustakaan digital, sistem manajemen pembelajaran, pencarian mesin, dan portofolio elektronik dan sebagainya selalu digunakan, untuk mencari sumber-sumber materi dari tugas yang diberikan. Hasil yang didapatkan pada pembelajaran online dengan menggunakan website sangat mempermudah peserta didik sehingga lebih fokus dalam proses belajar dikelas ataupun saat mereka berada di luar kelas.
\end{abstract}

Kata Kunci: Pembelajaran, E-Learning, Online

\section{A. Pendahuluan}


E-learning menurut Markus (2008) dapat didefinisikan sebagai proses pembelajaran yang dibuat oleh interaksi dengan konten yang disampaikan secara digital, layanan berbasis jaringan dan dukungan bimbingan. E-Learning adalah pembelajaran yang dimediasi secara teknologi menggunakan komputer baik dari jarak jauh atau dalam pengaturan kelas tatap muka (pembelajaran berbantuan komputer), ini merupakan pergeseran cara berfikir yang tradisional dalam pendidikan atau pelatihan untuk pribadi, fleksibel, individual, mandiri, berbasis ITC pembelajaran kolaboratif berdasarkan komunitas pelajar, guru, fasilitator, dan pakar.

Teknologi e-learning menawarkan kontrol mahasiswa atas konten, urutan pembelajaran, kecepatan belajar, waktu, dan seringkali media. Dalam mengelola akses ke materi e-learning, harus memahami bahasa program dalam hal ini adalah codding. Inovasi dalam teknologi e-learning mengarah pada revolusi dalam pendidikan, memungkinkan pembelajaran menjadi individual (pembelajaran adaptif), meningkatkan interaksi peserta didik dengan orang lain (Pembelajaran kolaboratif), dan mengubah peran guru. Integrasi e-learning ke dalam pendidikan dapat menjadi katalis perubahan menuju penerapan teori pembelajaran orang dewasa, di mana pendidik tidak akan lagi berfungsi terutama sebagai distributor konten, tetapi akan menjadi lebih terlibat sebagai fasilitator pembelajaran dan penilai kompetensi.

E-learning juga disebut pembelajaran berbasis web, pembelajaran online, didistribusikan pembelajaran, instruksi berbantuan komputer, atau pembelajaran berbasis internet. Secara historis, ada menjadi dua mode e-learning yang umum : pembelajaran jarak jauh dan instruksi berbantuan komputer. Pembelajaran jarak jauh menggunakan teknologi informasi untuk menyampaikan instruksi kepada peserta didik yang berada di lokasi terpencil dari situs pusat. Instruksi berbantuan komputer (juga disebut berbasis komputer pembelajaran dan pelatihan berbasis komputer) menggunakan komputer untuk membantu pengiriman yang berdiri sendiri paket multimedia untuk pembelajaran dan pengajaran. Pembelajaran multimedia. Multimedia menggunakan dua atau lebih banyak media, seperti teks, grafik, animasi, audio, atau video, untuk menghasilkan konten yang menarik 
bahwa peserta didik akses melalui komputer. Blended learning, istilah yang cukup baru dalam pendidikan tetapi konsep yang akrab bagi kebanyakan pendidik, adalah pendekatan yang menggabungkan teknologi e-learning dengan pelatihan yang dipimpin instruktur tradisional, di mana, misalnya, kuliah atau demonstrasi dilengkapi dengan tutorial online. Keadaan ini dapat dikategorikan sebagai proses pengiriman pembelajaran atau peningkatan pembelajaran.

\section{B. Masalah}

Peningkatan akses ke materi pendidikan sangat penting, karena pembelajaran seringkali tidak direncanakan pengalaman. Dan masih banyak Hal ini akan memperbarui konten elektronik lebih mudah daripada memperbarui materi cetak: e-learning teknologi memungkinkan pendidik untuk merevisi konten mereka secara sederhana dan cepat. Peserta didik memiliki kendali lebih dari konten, urutan pembelajaran, kecepatan belajar, waktu, dan, seringkali, media, yang memungkinkan mereka menyesuaikan pengalaman mereka untuk memenuhi tujuan pembelajaran pribadi.

\section{Metode Pelaksanaan}

Membuat materi e-learning melibatkan beberapa komponen: sekali konten dikembangkan, itu harus dikelola, dikirim, dan distandarisasi. Konten terdiri dari semua materi pengajaran, yang dapat berkisar dalam kompleksitas dari item diskrit hingga modul pembelajaran yang lebih besar. Pembelajaran digital objek didefinisikan sebagai pengelompokan materi digital yang terstruktur dengan cara yang bermakna dan terikat tujuan pendidikan.

\section{Pembahasan}

\section{Komponen E-Learning}

Membuat materi e-learning melibatkan beberapa komponen: sekali konten dikembangkan, itu harus dikelola, dikirim, dan distandarisasi. Konten terdiri dari semua materi pengajaran, yang dapat berkisar dalam kompleksitas dari item diskrit hingga modul pembelajaran yang lebih besar. Pembelajaran digital objek didefinisikan sebagai pengelompokan materi digital yang terstruktur dengan cara yang bermakna dan terikat tujuan pendidikan. 
Objek pembelajaran mewakili unit materi instruksional yang terpisah dan mandiri berkumpul dan berkumpul kembali di sekitar tujuan pembelajaran tertentu, yang digunakan untuk membangun yang lebih besar materi pendidikan seperti pelajaran, modul, atau kursus lengkap untuk memenuhi persyaratan dari kurikulum yang ditentukan. Contohnya termasuk: tutorial, pembelajaran berbasis kasus, hypermedia, simulasi, dan berbasis game modul pembelajaran. Pembuat konten menggunakan desain instruksional dan prinsip-prinsip pedagogis untuk menghasilkan objek pembelajaran dan bahan ajar.

Manajemen konten mencakup semua fungsi administratif (mis., menyimpan, mengindeks, membuat katalog) diperlukan untuk membuat konten elearning tersedia untuk pelajar. Contohnya termasuk portal, repositori, perpustakaan digital, sistem manajemen pembelajaran, pencarian mesin, dan portofolio elektronik. Pengiriman konten yang sinkron atau asinkron

\section{Manfaat e-learning}

E-learning penting untuk pendidikan karena dapat meningkatkan kualitas pembelajaran pengalaman, dan memperluas jangkauan setiap dosen dan tutor.

E-learning dapat membantu menghilangkan hambatan untuk berprestasi, dengan menyediakan yang baru dan kreatif cara memotivasi dan melibatkan siswa dan pelajar dari semua kemampuan, memungkinkan dan menginspirasi setiap orang untuk mencapai potensi pendidikan mereka.

E-learning dapat mendukung pembelajaran dengan menawarkan pembelajaran yang berbeda, Terutama bagi mereka yang membutuhkan dukungan dalam melek huruf, berhitung dan TIK.

E-learning menawarkan berbagai alat untuk memungkinkan guru dan peserta didik menjadi inovatif, kreatif dan banyak akal dalam semua kegiatan pembelajaran. Guru dan peserta didik dapat dengan mudah menyesuaikan sumber belajar digital agar sesuai dengan kecepatan dan level, sesuai untuk pembelajaran apa pun gaya dan kemampuan.

E-learning menciptakan komunitas praktik on-line. Internet dapat membawa pelajar, guru, komunitas spesialis, pakar, praktisi, dan kelompok kepentingan bersama untuk berbagi ide dan praktik yang baik. 
E-learning dapat memberikan pengalaman belajar individual untuk semua peserta didik, termasuk mereka yang kurang beruntung, cacat, berbakat luar biasa, memiliki kurikulum khusus atau kebutuhan belajar atau yang jauh atau jauh dari tempat belajar mereka yang biasa.

E-learning dapat memfasilitasi partisipasi yang lebih luas dan akses yang lebih adil untuk lebih jauh dan lebih tinggi pendidikan dengan menciptakan kesempatan untuk mulai belajar dan memilih kursus dan mendukung sesuai dengan kebutuhan peserta didik.

E-learning memberikan dukungan pembelajaran yang dipersonalisasi melalui informasi, saran, dan layanan bimbingan. Ini dapat membantu peserta didik menemukan kursus yang mereka butuhkan, dengan mulus transisi ke tahap berikutnya dari pembelajaran mereka, termasuk aplikasi atau pendaftaran online dan portofolio elektronik untuk pembelajaran mereka.

E-learning menyediakan dunia belajar virtual di mana peserta didik dapat mengambil bagian dalam aktif dan pembelajaran kreatif dengan orang lain melalui simulasi, permainan peran, kendali jarak jauh alat dan perangkat dunia nyata, kelas master online, atau kolaborasi dengan pendidikan lain penyedia layanan.

\section{E. Kesimpulan}

E-learning adalah pasar yang besar dan terus berkembang dengan potensi besar dalam pendidikan tinggi. (Berarti et al, 2009). Dalam studi empirisnya dari tahun 1996 dan 2008 disimpulkan bahwa siswa menggunakan e-learning tampil lebih baik daripada siswa yang tidak menggunakan e-learning. Para siswa yang berprestasi terbaik adalah mereka yang menerima blended learning. Untuk memaksimalkan potensi ini, implementasi e-learning harus diupayakan memenuhi kebutuhan dan keprihatinan semua kelompok pemangku kepentingan sebanyak mungkin. 


\section{DAFTAR PUSTAKA}

Organization for Economic Co-operation and Development. Education today: The OECD Perspective. OECD, 2009.

Wenglinsky, Harold. The Relationship between Educational Technology and Student Achievement in Mathematics. ETS Policy Information.

Bourner, T. \& Flowers, S. (1997). Teaching and learning methods in higher education: A glimpse of the future. Reflections on Higher Education, 9, 77-102.

Singh, G. \& Priola, V. (2001). Long distance learning and social networks: An investigation into the social learning environment on online students. Proceedings of the Sixth Annual ELSIN Conference. 158-164.

Kayte O'Neill, Gurmak Singh, and John O'Donoghue ( February 2004): Implementing eLearning Programmes for Higher Education: A Review of the Literature: Journal of Information Technology Education Volume 3, 2004. University of Wolverhampton, Wolverhampton, UK.

The Role of Technology and Its Impact on Education, Summary Report. November 2008

Singh, G. \& Priola, V. (2001). Long distance learning and social networks: An investigation into the social learning environment on online students. Proceedings of the Sixth Annual ELSIN Conference. 158-164. 